\title{
Behavioral Workplace Competencies: Analyzing a Competency Model for Private Companies
}

\author{
Fernando Fierro ${ }^{1}$, Juan M. Andrade ${ }^{2}$, Elías Ramírez ${ }^{1}$ \\ ${ }^{1}$ Universidad de Surcolombiana - Usco, Colombia \\ ${ }^{2}$ Corporación Universitaria Minuto de Dios - Uniminuto, Colombia
}

\begin{abstract}
This article analyzes the model of behavioral workplace competencies in the private sector to discern the suitability of a model proposed in the private sector and its applicability in the public sector, as well as the competencies stipulated in Colombian regulations. It can be therefore characterized as a quantitative study carried out using the deductive and descriptive method. The sample used exceeded 120 Likert-type surveys in various national public sector organizations. One of the most relevant results was the distant relationship between the two models, private and public sector, meaning that the relationship between both is statistically insignificant.
\end{abstract}

Keywords - Workplace competencies, Organizational behavior.

\section{Introduction}

The human resource is an important factor within organizations. It allows any administrative action within a framework of organizational change to succeed or fail [1], as well as to achieve objectives [2].

DOI: $10.18421 /$ TEM102-35

https://doi.org/10.18421/TEM102-35

Corresponding author: Juan M. Andrade, Corporación Universitaria Minuto de Dios - Uniminuto, Colombia.

Email: jandradenav@uniminuto.edu.co

Received: 10 January 2021.

Revised: 25 March 2021.

Accepted: 01 April 2021.

Published: 27 May 2021.

(cc) BY-NC-ND (C) 2021 Fernando Fierro, Juan M. Andrade \& Elías Ramírez; published by UIKTEN. This work is licensed under the Creative Commons AttributionNonCommercial-NoDerivs 4.0 License.

The article is published with Open Access at www.temjournal.com
Within the administrative theories of human resource management, workplace competencies that help the evolution of the individual as an element of development [3] within an organization is studied for the fulfillment of organizational objectives which answer to an external diagnosis [4]. The usefulness of a model for managerial workplace competencies elaborated and validated in private organizations of different sectors, will be assessed from the behavioral approach proposed by Spencer \& Spencer [5] as the basis for a competent manager.

When institutions, both private and public, are analyzed, the differences between public and private management stand out, recognizing greater efficiency in the latter [6], [7]. In this case, the vision of improvement between the two directors is made from the perspective of managerial workplace competencies considering the perspective of the behavioral school of management, with the aim of knowing the usefulness of competencies in the public sector.

There are two kinds of organizations: private and public companies. This can change the role of managers [8] depending on the organizational and financial goals [9] set in the organizational process. Once the goals have been established, it is important to know the skills [10] that managers have to possess to better conduct their work.

\section{Literature Review}

\subsection{Workplace Competencies}

The first seminal author considered in regards to competencies is McClelland [11]. He reflected on the use and validity of intelligence and aptitude tests applied in schools, universities and companies, which greatly affect people, since they are classified as "qualified" and "underqualified". The author raised concerns such as: Why should intelligence tests have all this power? What justifies the use of these tests in the admission of people to universities 
and jobs? Under what assumptions is the success of this movement based on this predictive test?

McClelland [11] followed graduates from the most prestigious colleges, considered a relevant credential to obtain jobs of great importance at the time, and found no difference between the high and low ranking students (now professionals) in their job performance. He came to the conclusion that the success of an individual in their work was due more to characteristics of their personality - that is, to their competencies- than to aspects such as knowledge and skills, criteria used as main factors of selection. This made it necessary to search for new variables, which he called competencies, which would allow to better predicting job performance. Competencies are now linked to a way of evaluating what seems to really cause superior work performance, rather than assessing factors that reliably describe a person, in the hope that some of those characteristics are associated with performance at work [12].

In the process of understanding cultural differences for the word "competency", different lines of thought identify the way to approach them, their contributions and limitations for organizations. Mertens [13] classifies three currents: the behavioral school, the functionalist and the holistic. Saracho [14] considers the latter to be a methodology rather than an approach itself. Each of them was developed according to their approach in each country [15], [16].

Organizing the relationship between competencies and the different ways of establishing them allows opening new academic spaces regarding the way they should be analyzed. The behavioral current considers personal attributes. The functional current considers functions or roles. And the constructivist current studies the union between worker and company.

Based on cross-cultural nuances, the focus or emphasis of the word competencies shifts from the individual to a job and that depends on the language or country. In the German linguistic context, it is understood as the ability or capacity of an individual to act within a defined work process. In English, the emphasis is on activities and task-based skills, rather than on the job itself. And in French, the term is particularly associated with continuing vocational education and human resource development [17], [18].

\subsection{Management Competencies}

The evolution of organizations has led academics to expand their lines of research regarding the worker as a fundamental resource of the organization. These investigations have triggered the emergence of workplace competencies (explained in the previous section), which in turn has opened the doors to the creation of competency models that serve to obtain better management direction.

Competency models have been investigated since the 1970s by Professor David McClelland, who heeded a call from the United States Information Agency (USIA) to recognize and correct errors in the agency's staff selection process. The professor's work on personality tests, attitudes and habits in high-performance groups was used to identify what high achievers are doing well [19].

As a result of these first studies, a concern arose regarding the generic way in which the origins of the models and the competencies of different jobs were being researched, based on the different experiences in the selection and retention processes of successful personnel in the organization.

In this academic process, influenced by McClelland, Boyatzis [20] identified six sources or origins for the elaboration of management competencies models, classified as follows (see Table 1):

Table 1. Management models and sources of production

\begin{tabular}{cl}
\hline Model & \multicolumn{1}{c}{ Source } \\
\hline Theoretical & $\begin{array}{l}\text { Of the theoretical proposals of } \\
\text { some scholars. }\end{array}$ \\
\hline Panel & $\begin{array}{l}\text { From a group of people inside and } \\
\text { outside the organization. }\end{array}$ \\
\hline $\begin{array}{c}\text { Ambiguous } \\
\text { tradition }\end{array}$ & Personal interpretations. \\
\hline $\begin{array}{c}\text { Tasks and } \\
\text { functions }\end{array}$ & $\begin{array}{l}\text { From the history of the } \\
\text { organization. }\end{array}$ \\
\hline $\begin{array}{l}\text { Oystematic } \\
\text { byservation daily work. }\end{array}$ & $\begin{array}{l}\text { From the investigations of the } \\
\text { behaviors of the managers of the } \\
\text { organizations. }\end{array}$ \\
\hline
\end{tabular}

Source. Own elaboration 
The purpose of identifying the origins of the previous models is to determine manager characteristics that are related to the effective development of the different types of management and in a wide variety of organizations, so they achieve the objectives set by the firm [20].

Lucia \& Lepsinger [19], based on the contributions of Dubois [21], propose other origins and sources of the elaboration of management models classified as follows (see Table 2):

Table 2. Models to identify competencies

\begin{tabular}{ll}
\hline \multicolumn{1}{c}{ Model } & \multicolumn{1}{c}{ Source } \\
\hline $\begin{array}{l}\text { Labor competence } \\
\text { assessment model }\end{array}$ & $\begin{array}{l}\text { Identification of the difference } \\
\text { between exceptional } \\
\text { development and average } \\
\text { development. }\end{array}$ \\
\hline $\begin{array}{l}\text { Modification of } \\
\text { labor competence } \\
\text { model }\end{array}$ & $\begin{array}{l}\text { Identification of difference in } \\
\text { behaviors, between high } \\
\text { performers and average } \\
\text { performers. }\end{array}$ \\
\hline Generic model & $\begin{array}{l}\text { Generic competition arising } \\
\text { outside the organization. }\end{array}$ \\
\hline $\begin{array}{l}\text { Custom generic } \\
\text { model }\end{array}$ & $\begin{array}{l}\text { Specific competences of the } \\
\text { organization. }\end{array}$ \\
\hline $\begin{array}{l}\text { Flexible model of } \\
\text { labor competence }\end{array}$ & $\begin{array}{l}\text { Identification of competencies to } \\
\text { develop effectively under } \\
\text { different conditions in the future. }\end{array}$ \\
\hline Systemic method & $\begin{array}{l}\text { Identify exemplary performances } \\
\text { in the present and in future } \\
\text { scenarios. }\end{array}$ \\
\hline $\begin{array}{l}\text { Accelerated } \\
\text { method of } \\
\text { competition }\end{array}$ & $\begin{array}{l}\text { Identify competencies that } \\
\text { support the results of the } \\
\text { organization. }\end{array}$ \\
\hline
\end{tabular}

Source. Own elaboration

Another methodology used for the elaboration of the model is the traditional analysis of positions or functions, a technique used to identify workplace competencies inherent to a productive function. This function can be defined at the level of an occupational sector, a company, a group of companies or a sector of production or services. This method is not exact; it is a work approach in order to review the required competencies through a deductive strategy [22].

On the other hand, the occupational studies method uses the multipurpose occupational systems analysis inventory (Mosaic) commonly used in the United States by the United States Office of Personnel Management (OPM), office of administrative personnel. It consists of a survey based on job analysis used to collect information from various groups with a wide range of human resources functions. The objective of this system is to develop a common language for competencies and to generalize tasks that can be used to describe all occupations [23].

The difference between the two functional analysis methods (see Table 3) is found in the following variables:

Table 3. Difference between models of functional competencies

\begin{tabular}{|c|c|c|}
\hline Variable & Mosaic approach & Traditional analysis \\
\hline Focus & $\begin{array}{l}\text { The study is } \\
\text { carried out in } \\
\text { groups, reducing } \\
\text { time and } \\
\text { resources }\end{array}$ & $\begin{array}{l}\text { The study is done one } \\
\text { at a time, which is } \\
\text { costly in terms of time } \\
\text { and resources }\end{array}$ \\
\hline Tasks & $\begin{array}{l}\text { Widely defined, } \\
\text { the breadth of } \\
\text { task definition is } \\
\text { strengthened }\end{array}$ & $\begin{array}{l}\text { Defined with a high } \\
\text { degree of specificity } \\
\text { and easily out of date }\end{array}$ \\
\hline Specificity & $\begin{array}{l}\text { Set of common } \\
\text { competencies and } \\
\text { tasks compared to } \\
\text { all jobs }\end{array}$ & $\begin{array}{l}\text { Knowledge, skills and } \\
\text { tasks are not performed } \\
\text { compared to all jobs }\end{array}$ \\
\hline Integration & $\begin{array}{l}\text { Ease of } \\
\text { integration with } \\
\text { human resource } \\
\text { administration }\end{array}$ & $\begin{array}{l}\text { Not integrated with } \\
\text { human resources; } \\
\text { initiatives come from } \\
\text { teams and people }\end{array}$ \\
\hline
\end{tabular}

Source: Own adaptation based on Rodriguez et al. (2002)

By providing a common language, the organization can build a system that uses a set of tasks and competencies to structure job functions, classification, recruitment, selection and staff development. This system provides all personnel with a consistent message about the elements necessary for selection, evaluation and training. The purpose is to make people know what the requirements are for the development of their work [23].

Once the methods proposed by the different authors have been reviewed, it can be determined that a competency model has to describe the combination of knowledge, skills and characteristics necessary to effectively take on a role in an organization and is used as a tool for human resources for the selection, training, evaluation and succession of plans [24].

Lucia \& Lepsinger [19] study the development of methods to create models, and argue that before starting the process of elaboration of the competency model, there has to be a solid base which has to take into account four areas (see Table 4): 
Table 4. Areas that have to be developed prior to the model

\begin{tabular}{ll}
\hline Areas & \multicolumn{1}{c}{ Development } \\
& $\begin{array}{l}\text { Identify business needs or needs that } \\
\text { the competencies can address. }\end{array}$ \\
& $\begin{array}{l}\text { Identify the jobs, functions or business } \\
\text { units that the model will address. }\end{array}$ \\
Determine the method for developing \\
the competency model. \\
Determine the composition of the \\
project team.
\end{tabular}

Source: Own adaptation based on Lucia \& Lepsinger (1999)

Once the four areas of the solid base of the model have been developed, the importance of data collection by the company is considered, which is organized as follows (see Table 5):

Table 5. Data collection

Data collection Development

Determining the methodology of data collection learn about critical incidents and history that reflect the effective development of the role for the analyzed work.

It is important to manage the time and the designated schedule to

Conducting the interviews and focus group carry out interviews, therefore it is important to provide a preliminary questionnaire with the important concerns.

Making

observations of Interviews are an important source work development

Analyzing the data and internally developing a competency model of data and it is important to conduct them with the job holder.

Data collection analysis can result in a preliminary list of skills, knowledge and characteristics required for the job, referred to as an internal competency model.
For model development, it has to be validated in order to highlight the precision and relevance of the data of the key jobs that were determined at the beginning of the four areas.

The model with the greatest acceptance among the ones discussed, due to its academic rigor in the elaboration and identification of competencies, is the Job Competency Assessment Method, developed by the McBer Company staff. It is composed of five steps [20] (see Table 6):

Table 6. Methods of evaluation of workplace competencies

\begin{tabular}{|c|c|c|}
\hline Steps & Activities & Results \\
\hline 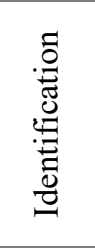 & $\begin{aligned} & \checkmark \text { Choose an } \\
& \text { appropriate job } \\
& \text { performance } \\
& \text { average. } \\
& \checkmark \text { Collect data from } \\
& \text { managers. }\end{aligned}$ & $\begin{array}{l}\checkmark \text { Job performance } \\
\text { data of } \\
\text { managers. }\end{array}$ \\
\hline 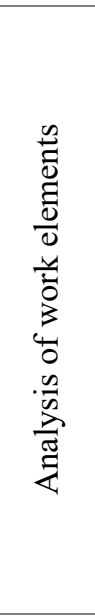 & $\begin{array}{l}\checkmark \text { Generate the list } \\
\text { of perceived } \\
\text { characteristics to } \\
\text { lead to higher } \\
\text { effectiveness } \\
\text { and/or } \\
\text { development. } \\
\checkmark \text { Get ratings of } \\
\text { items by } \\
\text { administrator. } \\
\checkmark \text { List of weighted } \\
\text { average } \\
\text { characteristic. } \\
\checkmark \text { Feature Cluster } \\
\text { Analysis. }\end{array}$ & $\begin{array}{l}\checkmark \text { A list of the } \\
\text { weighted } \\
\text { average of the } \\
\text { characteristics } \\
\text { perceived by the } \\
\text { administrators to } \\
\text { report the } \\
\text { superior } \\
\text { development. } \\
\checkmark \text { List of clusters } \\
\text { within which } \\
\text { these } \\
\text { characteristics } \\
\text { can be grouped. }\end{array}$ \\
\hline 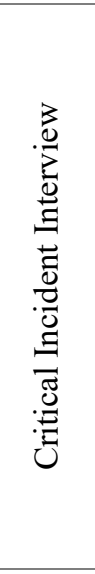 & $\begin{array}{l}\checkmark \text { Conduct the critical } \\
\text { incident interview. } \\
\checkmark \text { Code the interviews } \\
\text { by characteristics } \\
\text { or develop the code } \\
\text { and then code the } \\
\text { interviews. } \\
\checkmark \text { Relating the code } \\
\text { to job performance } \\
\text { data. }\end{array}$ & $\begin{array}{l}\checkmark \text { List of } \\
\text { hypothetical } \\
\text { characteristics to } \\
\text { distinguish } \\
\text { effective and/or } \\
\text { superior } \\
\text { development } \\
\text { from poor or } \\
\text { less effective job } \\
\text { performance. } \\
\checkmark \text { A list of } \\
\text { validated } \\
\text { characteristics or } \\
\text { competencies. }\end{array}$ \\
\hline
\end{tabular}

Source: Own adaptation based on Lucia \& Lepsinger (1999) 


\begin{tabular}{|c|c|c|c|}
\hline 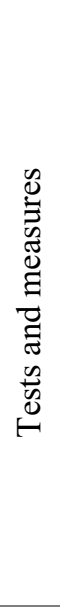 & $\begin{array}{l}\checkmark \\
\checkmark \\
\checkmark \\
\checkmark\end{array}$ & $\begin{array}{l}\text { Choose the tests } \\
\text { and measures to } \\
\text { assess the } \\
\text { identified } \\
\text { competencies, } \\
\text { prioritizing the } \\
\text { first two steps as } \\
\text { relevant to job } \\
\text { performance. } \\
\text { Administer, } \\
\text { measure and grade } \\
\text { tests. } \\
\text { Report score of } \\
\text { job performance } \\
\text { data. }\end{array}$ & $\begin{array}{l}\checkmark \text { A list of validated } \\
\text { characteristics or } \\
\text { competencies } \\
\text { valued by those } \\
\text { tests and } \\
\text { measures. }\end{array}$ \\
\hline 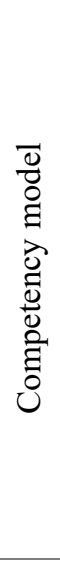 & $\checkmark$ & $\begin{array}{l}\text { Integrate the } \\
\text { results prioritizing } \\
\text { the first three } \\
\text { steps. } \\
\text { Statistically and } \\
\text { theoretically } \\
\text { determine and } \\
\text { document the } \\
\text { causal relationship } \\
\text { between } \\
\text { competencies and } \\
\text { between } \\
\text { competencies and } \\
\text { job performance. }\end{array}$ & $\begin{array}{l}\checkmark \text { Validation of the } \\
\text { competency } \\
\text { model. }\end{array}$ \\
\hline
\end{tabular}

Source: Boyatzis (1982)

For Boyatzis [20], the first step is to examine the components in the relationship of the measures and job development, because the measure only reflects the actual development of the person who assesses it. The second step is considered as a list of characteristics that is generated in brainstorming group sessions. This group of people is asked the characteristics that distinguish superior development from average development. The third step is data collection through the critical incident interview methodology. It inquires about three incidents in which the interviewees have felt effective at work, and three incidents in which they have felt ineffective at work. The fourth step, after having assessed and recognized the corresponding characteristics, is to apply statistical methods that contain validity in the choice of the sample and reliability in the response of the interviewees. As the last step, it is developed through the grouping and validation of competencies through statistical and non-statistical methods.

Other authors who have been very well received in the application of the Job Competency Assessment are Spencer \& Spencer [5]. They modified the general scheme and propose six steps ordered as follows: a. Define the criteria for effective development

b. Sample identification and criteria

c. Data collection

d. Data analysis and competency model development

e. Validation of the competency model

f. Preparation of the application of the competencies model

In order to successfully carry out the steps mentioned and proposed by Spencer \& Spencer [5], the authors recommend prioritizing the beginning of the model by identifying the needs of the organization, ideally of the key positions that are set forth to the strategic direction of the organization, elaboration of plans and structure and design, to carry out the proposed objectives. The systemic risk in model elaboration is thus reduced.

According to Spencer \& Spencer [5], the first step to study competencies is the identification of the measurement criteria that define effective higher development. The second step regards the effectiveness criteria evaluated and developed used to identify a clear group of superstars, and compared with an average group of identified workers. The third step, data collection, varies according to the style and model of competencies used. They propose six data collection methodologies:
a. Critical Incident Interview
b. Expert Panel
c. Polls
d. Expert based model
e. Analysis of functions and tasks
f. Direct observation

In the fourth step, the data from all sources and methods are analyzed to identify the personality and skills that distinguish higher development. In the fifth step, the model can be validated in three ways:

a. Cross validation: the model is validated in another group to know the results.

b. Construct validation: different constructs or measures are used to evaluate competencies and predict the performance of people at a certain point of time.

c. Predictive validation: competency molding is expected to be predictive in the higher performance of individuals' work

The three methods used in the validation of the model are the key in selection and training processes of new personnel. They should be hired using the criteria to predict their development, and trained in the skills needed to do their job well [5]. 
In the sixth step, the applications of the competencies model are taken into account [20]:

a) Selection of personnel based on competencies; b) Test as an assessment measure; c) Employee Assessment Center; d) Career plan; e) Personal development; f) Succession plans; g) Training and development; h) Compensation systems; i) Employee information systems, and; j) Staff evaluation.

It is important to carry out the applications in a comprehensive way for their best operation. Instead of only identifying the necessary competencies within the organization and making them known, the methodology has to be transversally applied. It is useless to have them if they are not applied in all areas. For instance, having the competencies and demanding them from employees without having a higher development-oriented compensation system is a demotivating factor for their development.

\subsection{Management Competencies Application Model}

The application of the competency models (see Table 7) has two approaches. The first seeks to demonstrate the repeatable ability of individuals or groups to achieve actions with some guaranteed level of result. The second is based on the inputs that people or organizations provide to achieve the objectives [25].

Table 7. Typologies of meaning

\begin{tabular}{clll}
\hline Individual & Corporate & Purpose \\
\hline Input & $\begin{array}{l}\text { Performance } \\
\text { standards }\end{array}$ & $\begin{array}{l}\text { Best } \\
\text { practices } \\
\text { skills and } \\
\text { abilities }\end{array}$ & $\begin{array}{l}\text { Performance } \\
\text {-based goal } \\
\text { (Training) }\end{array}$ \\
\hline e strengths & $\begin{array}{l}\text { Distinctiv } \\
\text { interest in } \\
\text { the subject } \\
\text { (Education) }\end{array}$ \\
\hline
\end{tabular}

Source: Hoffmann (1999)

For the process of this study, the way the typologies are presented are the basis for starting the identification of the variables. Spencer \& Spencer's [5] model provides input, and the organization's performance is output, in which the variables are later identified [18].
Based on the inputs, and for the purposes of the elaboration of the management competencies model proposed by Spencer \& Spencer [5], the starting point is McBer's research, reviewing the competencies found in more than 200 workplaces. To be able to analyze all these models, a common ground is needed. A common language was thus used, a step that is similar to coding in the quantitative study of meta-analysis.

It was necessary to do so due to the number of studies carried out in nearly 20 years by more than 100 researchers on the subject, using different names for similar competencies. This new list was made with behavioral indicators that appeared in 286 competency models, where approximately 760 types of behaviors were identified based on these types. 21 competencies, contributed by $80 \%$ to $98 \%$ of behaviors reported in each model, are identified.

This list provides a preliminary dictionary where all the competencies were coded using the behavioral indicators. The interview for critical incidents was used based on a sample of 187 (66\%) American industries and 98 (34\%) studies carried out in 20 different countries or with the holders of the jobs of multinationals analyzed in 3 or 10 countries.

After having carried out this step, the authors use the job competency assessment method (JCA) to identify the generic management model of job skills, based on the following (see Table 8):

Table 8. Characteristics of the generic model sample

\begin{tabular}{cl}
\hline Variables & \multicolumn{1}{c}{ Characteristics } \\
\hline Level & $\begin{array}{l}\text { From the first supervisory level to the } \\
\text { executive }\end{array}$ \\
\hline Function & $\begin{array}{l}\text { Production, sales, marketing, finance, } \\
\text { engineering, human resources }\end{array}$ \\
\hline Industria & $\begin{array}{l}\text { Military, health or medical care sector, } \\
\text { education, manufacturing }\end{array}$
\end{tabular}

Source: Spencer \& Spencer (1993)

Based on the characteristics and methodology mentioned above, the model (see Table 9) of management competencies of Spencer \& Spencer [5] emerges, where management competencies are determined as a specialized set of impact and influence competencies, expressing the intention to have some specific effect. This specific intention (to develop others, mentor others, to improve teamwork and cooperation) is particularly important to managers. 
Table 9. Spencer \& Spencer's (1993) management competencies model

\begin{tabular}{|c|c|}
\hline Competency & Definition \\
\hline $\begin{array}{l}\text { Impact and } \\
\text { influence }\end{array}$ & $\begin{array}{l}\text { Evidence of the intention to persuade, } \\
\text { influence, convince or impress others in } \\
\text { order to obtain their support for the } \\
\text { interests of the speaker or seeking a } \\
\text { specific impact on others }\end{array}$ \\
\hline $\begin{array}{l}\text { Orientation } \\
\text { towards } \\
\text { achievement }\end{array}$ & $\begin{array}{l}\text { It is a concern to do the job well or to } \\
\text { compete against a standard of excellence. } \\
\text { This standard may be the individual's past } \\
\text { performance (seeking improvement); an } \\
\text { objective measure (results orientation); } \\
\text { the performance of others } \\
\text { (competitiveness); challenging goals set } \\
\text { by the individual; or even what no one } \\
\text { has ever done (innovation). }\end{array}$ \\
\hline $\begin{array}{l}\text { Teamwork } \\
\text { and } \\
\text { cooperation }\end{array}$ & $\begin{array}{l}\text { It implies a sincere willingness to work } \\
\text { with others, to be part of a team, to work } \\
\text { together to achieve specific goals, and not } \\
\text { working separately. }\end{array}$ \\
\hline $\begin{array}{l}\text { Analytical } \\
\text { thinking }\end{array}$ & $\begin{array}{l}\text { Ability to understand a situation from its } \\
\text { fragmentation into several smaller parts. } \\
\text { Ability to know how to organize a } \\
\text { problem or situation in a systemic way, } \\
\text { carry out systemic comparisons, establish } \\
\text { rationally founded priorities, identify } \\
\text { temporal sequences and cause-effect } \\
\text { relationships that occur, analyze and } \\
\text { organize numerical data. }\end{array}$ \\
\hline Initiative & $\begin{array}{l}\text { Competition oriented to unforeseen or } \\
\text { expected action. Initiative is doing more } \\
\text { than what is required or expected at work. } \\
\text { It implies an active search for new } \\
\text { opportunities to improve activities in } \\
\text { another way that nobody has asked for, or } \\
\text { knowing how to find new opportunities. }\end{array}$ \\
\hline $\begin{array}{c}\text { Developmen } \\
\mathrm{t} \text { of others }\end{array}$ & $\begin{array}{l}\text { This competition aims to teach or } \\
\text { encourage the development of one or } \\
\text { more people at all levels. The essence of } \\
\text { this competency is to achieve } \\
\text { development rather than fulfill a formal } \\
\text { role. }\end{array}$ \\
\hline $\begin{array}{c}\text { Self- } \\
\text { confidence }\end{array}$ & $\begin{array}{l}\text { A person believes in their own potential } \\
\text { to carry out a task, has personal } \\
\text { confidence to face very demanding } \\
\text { situations, makes decisions or gives } \\
\text { opinions, and manages mistakes } \\
\text { constructively. }\end{array}$ \\
\hline $\begin{array}{l}\text { Being } \\
\text { directive/ass } \\
\text { ertive }\end{array}$ & $\begin{array}{l}\text { It expresses the individual purpose of } \\
\text { making others comply with your wishes. } \\
\text { Directing behavior has the component of } \\
\text { telling people what to do on a specific } \\
\text { topic and with an appropriate tone. The } \\
\text { effectiveness is typical of the manager. } \\
\text { Assertively use the power of having a } \\
\text { certain position to achieve good results. }\end{array}$ \\
\hline
\end{tabular}
Search for search for information. The search for information information implies making an effort to gather more information, not settling for what is already available or its nominal value.

Express the intention of assuming the role of the leader of a team or a group of people. It implies the will to lead others. Team leadership is generally, but not Team always, associated with a formal position leadership of authority. Normally, it is combined with the competency of teamwork. It must be exercised responsibly, that is, it must be used in favor of the interests of the organization over personal interests.

It implies understanding a situation or a problem from several loose pieces and seeing its universality. This means knowing how to identify the models and connections between situations that are Conceptual not obvious, identifying the key or thinking fundamental aspects of complex situations. Conceptual thinking is applied to existing concepts or to create new concepts, inductive, creative or conceptual reasoning.

Source: Spencer \& Spencer (1993)

Although this model identifies 11 competencies for managers, there are competencies that complement the model, such as: organizational awareness, relationship building and professional expertise. In addition, it has to be taken into account that behind a generic profile there is a particular dimension (level, function and industry), which allows the competencies to have greater or lesser importance, for which more or less emphasis should be given. Based on the characteristics of the industry and the company, the authors point out that although the management models seem similar, this does not constitute any argument to think that a manager can manage anything at any price [26], [27].

For the purposes of this article, the competency model to be used is Spencer \& Spencer's [5]. Although many studies have been developed on the subject of competencies, resulting in countless classifications for different work areas and different production sectors, the generic model proposed by Spencer \& Spencer is the most complete as it is based on 36 models, resulting in 12 basic competencies that a manager must have. Likewise, this model is based on the fact that the managers of any organization share the general profile of competencies. 
There are other studies based on the Spencer \& Spencer model. Candel [28] exposes the author's model to analyze the performance of a company in the gaming sector. In turn, the model crosses professions in the field of jurisprudence with the study by Sánchez [29], where the competencies of lawyers are developed. Furthermore, Burke et al. [30] propose the same methodology for the health sector, applying it to the competencies of pharmacists. Another sector that used the model was that of physical education with the study by Medina, Milan \& Ríos [31], where the authors proposed developing skills for soccer players.

The latest trends refer to the competencies that new professionals must face, as stated by Boyatzis \& Boyatzis [32], who outline that new managers must possess different competencies in the 21 st century in order to respond to new market needs. At the same time, the studies of Boyatzis, Goleman \& Rhee [33] have encouraged discussing the subject of competencies with emotional intelligence raised by Goleman [34], proposing a cluster of competencies regarding emotional intelligence.

The development and growth of an organization depends on how good and timely decisions are made, and this responsibility falls on the manager. Therefore, this person must have competencies that allow them to always make the best decision for the benefit of their organization.

\subsection{Colombian Regulations}

The current Colombian regulations related to public employment are hereby outlined (see Table 10):

Table 10. Colombian regulations related to public employment

\begin{tabular}{cll}
\hline Regulations & \multicolumn{1}{c}{ Function } & Orientation \\
\hline Ibero- & $\begin{array}{l}\text { Defines the bases that } \\
\text { make up a professional and }\end{array}$ \\
American & $\begin{array}{l}\text { effective public service } \\
\text { Charter of } \\
\text { system. }\end{array}$ & Functional \\
Function & $\begin{array}{l}\text { Configures a generic } \\
\text { framework of guiding } \\
\text { principles. }\end{array}$ & \\
& $\begin{array}{l}\text { Issues which rules regulate } \\
\text { public employment, } \\
\text { administrative } \\
\text { public management and } 909 \\
\text { other provisions. }\end{array}$ \\
\hline Establishes the procedure \\
to be provided before and \\
by the National Civil \\
Secree 760 \\
$\begin{array}{l}\text { Service Commission for } \\
\text { the fulfillment of its } \\
\text { functions. }\end{array}$
\end{tabular}

\begin{tabular}{|c|c|c|}
\hline $\begin{array}{l}\text { Decree } 765 \\
\quad(2005)\end{array}$ & $\begin{array}{l}\text { Modifies the specific } \\
\text { career system } r \text { of } \\
\text { employees of the Special } \\
\text { Administrative Unit for } \\
\text { National Taxes and } \\
\text { Customs. }\end{array}$ & Functional \\
\hline $\begin{array}{l}\text { Decree } 770 \\
\quad(2005)\end{array}$ & $\begin{array}{l}\text { Establishes the system of } \\
\text { functions and general } \\
\text { requirements for public } \\
\text { jobs corresponding to the } \\
\text { hierarchical levels } \\
\text { belonging to the agencies } \\
\text { and entities of the national } \\
\text { order to which Law } 909 \text { of } \\
2004 \text { refers. }\end{array}$ & Functional \\
\hline $\begin{array}{l}\text { Decree } 775 \\
\quad(2005)\end{array}$ & $\begin{array}{l}\text { Establishes the specific } \\
\text { system of administrative } \\
\text { career for the } \\
\text { superintendencies of the } \\
\text { national public } \\
\text { administration. }\end{array}$ & Functional \\
\hline $\begin{array}{l}\text { Decree } 780 \\
\quad(2005)\end{array}$ & $\begin{array}{l}\text { Establishes the specific } \\
\text { career system for } \\
\text { employees of the } \\
\text { Administrative Department } \\
\text { of the Presidency of the } \\
\text { Republic. }\end{array}$ & Functional \\
\hline $\begin{array}{l}\text { Decree } 785 \\
\quad(2005)\end{array}$ & $\begin{array}{l}\text { Establishes the } \\
\text { nomenclature and } \\
\text { classification system and } \\
\text { the functions and general } \\
\text { requirements of the jobs of } \\
\text { the territorial entities that } \\
\text { are regulated by the } \\
\text { provisions of Law } 909 \text { of } \\
2004 \text {. }\end{array}$ & Functional \\
\hline $\begin{array}{c}\text { Decree } \\
1227 \\
(2005)\end{array}$ & $\begin{array}{l}\text { Partially regulates Law } 909 \\
\text { of } 2004 \text { and Decree Law } \\
567 \text { of } 1998 .\end{array}$ & Functional \\
\hline $\begin{array}{l}\text { Decree } \\
1228 \\
(2005)\end{array}$ & $\begin{array}{l}\text { Regulates article } 16 \text { of Law } \\
909 \text { of } 2004 \text { on personnel } \\
\text { commissions. }\end{array}$ & Functional \\
\hline $\begin{array}{l}\text { Decree } \\
2539 \\
(2005)\end{array}$ & $\begin{array}{l}\text { Establishes the general } \\
\text { workplace competencies } \\
\text { for public jobs at the } \\
\text { different hierarchical levels } \\
\text { of the entities to which } \\
\text { Decree Law } 770 \text { and } 785 \\
\text { apply. }\end{array}$ & Functional \\
\hline $\begin{array}{l}\text { Agreement } \\
127(2009)\end{array}$ & $\begin{array}{l}\text { Modifies and specifies } \\
\text { Agreement } 108 \text { of August } \\
6,2009 \text {. }\end{array}$ & Functional \\
\hline $\begin{array}{c}\text { Decree } \\
3626 \\
(2005)\end{array}$ & $\begin{array}{l}\text { Regulates Decree Law } 765 \\
\text { of } 2005 .\end{array}$ & Functional \\
\hline
\end{tabular}

Source: Own elaboration

The tool used for the analysis of the information was the TI Atlas [35] in order to know the orientation of public regulations. The analysis was carried out as follows: First, the three streams were coded under words that identify each school. Second, when 
establishing the coding, a close-up reading and coding of each of the laws and decrees was carried out. Finally, the Atlas TI word cloud tools were used to systematically identify the approach.

\section{Materials and Methods}

The methodology includes four subsections: (1) the approach, method and type of research is established; (2) the participants in the research are described; (3) the analysis of information.

\subsection{Approach and Method}

The research carried out was quantitative, approached from the deductive and descriptive method. It was oriented to two main parts: the first refers to the responses of public servants to the Spencer \& Spencer model [5], while the second part refers to the responses of public workers to Decree 2539 , proposed by the government.

\subsection{Population and Sample}

The institutions analyzed belong to the National, Departmental and Municipal order, in order to obtain the highest rank of public workers. The sampling was carried out at the researcher's convenience, carrying out a total of 127 surveys in the different institutions. The study subjects were people who hold administrative management positions in the institutions [36]. When conducting the analysis of competencies, the deductive method was used, that is, we started from the general to the particular in order to conclude the usefulness of the model in the public sector.

\subsection{Data Analysis}

Data collection was carried out directly in accordance with what was proposed by Cerda [37], the questionnaire was clearly structured, Likert type, with a scale from one to six, where one was the lowest and six, the highest.

To establish the construct reliability of the scale in the survey, Cronbach's Alpha is used, a measure that quantifies the correlation between the items that make up the questions stipulated in the instrument.

Cronbach's Alpha was estimated at 0.885 and, following González \& Pazmiño's parameters [38], it was determined that construct validity it agrees with the criteria established between 0.7 and 0.9 .

\section{Results and Discussion}

The results of the study are presented below.

\subsection{Model Analysis of Private Competencies}

In this part of the competencies, a descriptive analysis was carried out according to the data shown below (see Table 11).

Table 11. Frequencies of the Spencer \& Spencer model

\section{ValidLosseAverageMedianMode SD}

\begin{tabular}{|c|c|c|c|c|c|c|}
\hline ImpacIn & 127 & 3 & 4,77 & 5.000 & 6 & 1,35 \\
\hline TeWork & 127 & 3 & 5,73 & 6.000 & 6 & 0,62 \\
\hline DeveOt & 127 & 3 & 5,36 & 6.000 & 6 & 0,81 \\
\hline TeLead & 127 & 3 & 5,41 & 6.000 & 6 & 0,78 \\
\hline AchiOri & 127 & 3 & 5,68 & 6.000 & 6 & 0,58 \\
\hline SeeInfo & 127 & 3 & 5,57 & 6.000 & 6 & 0,64 \\
\hline ConThi & 127 & 3 & 5,37 & 6.000 & 6 & 0,75 \\
\hline AnaThi & 127 & 3 & 5,46 & 6.000 & 6 & 0,63 \\
\hline Inic & 127 & 3 & 5,53 & 6.000 & 6 & 0,69 \\
\hline SelfCo & 127 & 3 & 5,62 & 6.000 & 6 & 0,68 \\
\hline BeDire & 127 & 3 & 4,98 & 5.000 & 6 & 1,09 \\
\hline
\end{tabular}

For the people surveyed, it is determined that the most important competency is teamwork followed by achievement orientation. This occurs due to the lack of collaboration between public servants associated with contracting styles, which is $40 \%$ staff and $60 \%$ free appointed, by contract or provision of services.

The least important competency is that of impact and influence, presented by the number of years in office of the person. For this sample, 55\% of the people surveyed had been between one to three years, a situation that does not allow establishing a relationship to get the best result from people.

\subsection{Model Analysis of Decree 2539 Competencies}

In this part of the competencies, a descriptive analysis was carried out according to the data shown below (see Table 12).

Table 12. Frequencies of model of decree 2539 competencies

Valid Losses Average Median Mode SD

\begin{tabular}{ccccccc}
\hline OriResu & 127 & 3 & 5,69 & 6.000 & 6 & 0,54 \\
\hline OriUser & 127 & 3 & 5,73 & 6.000 & 6 & 0,55 \\
\hline Transp & 127 & 3 & 5,81 & 6.000 & 6 & 0,49 \\
\hline Comm & 127 & 3 & 5,69 & 6.000 & 6 & 0,55 \\
\hline Leader & 127 & 3 & 5,64 & 6.000 & 6 & 0,57 \\
\hline Planni & 127 & 3 & 5,64 & 6.000 & 6 & 0,59 \\
\hline DeciMa & 127 & 3 & 5,58 & 6.000 & 6 & 0,62 \\
\hline DeciPer & 127 & 3 & 5,58 & 6.000 & 6 & 0,59 \\
\hline KnoSu & 127 & 3 & 5,61 & 6.000 & 6 & 0,60 \\
\hline LeGrou & 127 & 3 & 5,59 & 6.000 & 6 & 0,69 \\
\hline DeMak & 127 & 3 & 5,63 & 6.000 & 6 & 0,59
\end{tabular}

Source. Own elaboration 
The most important competency for those surveyed was transparency, followed by orientation to the citizen. This occurs given that the raison d'être of public institutions is to attend to citizens' requests, as well as considering the moral hazard usually associated with transparency in all institutions.

The lower relativity occurs in two competencies. The first refers to decision-making: because people in the public sector are not autonomous, they must do what the law says. The second refers to directing the development of people: since $61 \%$ of the surveyed people have university or postgraduate degrees when they were hired, they feel that the institution does not care about their development of individuals.

\subsection{Analysis of the Relationship of the Two Models}

To know the relationship between the two models (private and public), the IT Atlas was used, establishing the analogy between the competencies of the different models. The chosen methodology refers to the main codes obtained from the private model to gather the comparison between the model public (see Table 13):

Table 13. Relationship between the competencies of the models

\begin{tabular}{cl}
\hline $\begin{array}{c}\text { Spencer \& Spencer } \\
\text { competency }\end{array}$ & \multicolumn{1}{c}{ Decree 2539 competency } \\
\hline $\begin{array}{c}\text { Impact and influence } \\
\text { cooperation }\end{array}$ & Orientation towards results \\
\hline $\begin{array}{c}\text { Development of } \\
\text { others }\end{array}$ & $\begin{array}{l}\text { Personnel direction and } \\
\text { development }\end{array}$ \\
\hline Team leadership & Leadership \\
\hline $\begin{array}{c}\text { Achievement } \\
\text { orientation }\end{array}$ & Transparency \\
\hline Seeking information & $\begin{array}{l}\text { Orientation to the user and the } \\
\text { citizen }\end{array}$ \\
\hline Conceptual thinking & Planning \\
\hline Analytical thinking & $\begin{array}{l}\text { Knowledge of the } \\
\text { surroundings }\end{array}$ \\
\hline Initiative & $\begin{array}{l}\text { Commitment to the } \\
\text { organization }\end{array}$ \\
\hline Self-confidence & $\begin{array}{l}\text { Decision making Personnel } \\
\text { administration }\end{array}$ \\
\hline Be directive & $\begin{array}{l}\text { Decision making Managerial } \\
\text { administration }\end{array}$ \\
\hline
\end{tabular}

Source: Own elaboration

Once the relationship was established, linear regressions were carried out between the Spencer model (dependent) and the model of Decree 2539 (independent variable). In this way, the relationship between the competencies of the two models is recognized (see Table 14).
Table 14. Linear regression of competencies

\begin{tabular}{|c|c|c|}
\hline $\begin{array}{l}\text { Spencer \& Spencer } \\
\text { competency }\end{array}$ & $\begin{array}{l}\text { Decree } 2539 \\
\text { competency }\end{array}$ & \\
\hline Impact and influence & $\begin{array}{l}\text { Orientation towards } \\
\text { results }\end{array}$ & 0.040 \\
\hline $\begin{array}{l}\text { Teamwork and } \\
\text { cooperation }\end{array}$ & $\begin{array}{l}\text { Leadership of work } \\
\text { groups }\end{array}$ & 0.022 \\
\hline $\begin{array}{l}\text { Development of } \\
\text { others }\end{array}$ & $\begin{array}{l}\text { Personnel direction } \\
\text { and development }\end{array}$ & 0.047 \\
\hline Team leadership & Leadership & 0.112 \\
\hline $\begin{array}{l}\text { Achievement } \\
\text { orientation }\end{array}$ & Transparency & 0.065 \\
\hline Seeking information & $\begin{array}{l}\text { Orientation to the } \\
\text { user and the citizen }\end{array}$ & 0.089 \\
\hline Conceptual thinking & Planning & 0.045 \\
\hline Analytical thinking & $\begin{array}{l}\text { Knowledge of the } \\
\text { surroundings }\end{array}$ & 0.058 \\
\hline Initiative & $\begin{array}{l}\text { Commitment to the } \\
\text { organization }\end{array}$ & 0.080 \\
\hline Self-confidence & $\begin{array}{l}\text { Decision making } \\
\text { Personnel } \\
\text { administration }\end{array}$ & 0.002 \\
\hline Be directive & $\begin{array}{l}\text { Decision making } \\
\text { Managerial } \\
\text { administration }\end{array}$ & 0.019 \\
\hline
\end{tabular}

Source: Own elaboration

When reviewing the regressions between the different competencies, it is determined that there is no correlation between them. The one that is most related is that of team leadership with that of leadership, a useful function in organizations.

To obtain an overview of the models and their correlation, two variables are established, given the sum of the competencies of the private sector, and the sum of the competencies of Decree 2539, remaining as follows (see Table 15):

Table 15. Summary

\begin{tabular}{ccccc}
\hline Model & $\mathbf{R}$ & $\begin{array}{c}\text { Square } \\
\text { R }\end{array}$ & $\begin{array}{c}\text { Adjusted } \\
\text { Square } \mathbf{R}\end{array}$ & $\begin{array}{c}\text { Standard } \\
\text { error }\end{array}$ \\
\hline 1 & .476 & .227 & .220 & 4.60661 \\
\hline
\end{tabular}

Source. SPSS (2020)

When analyzing the previous Table, it can be determined that in general there is no relationship between the two models.

Continuing with the line of descriptive analysis of the two total variables, the following Table is presented (see Table 16): 
Table 16. Descriptive analysis of the total variables

\begin{tabular}{crr}
\hline & Total Spencer & \multicolumn{1}{c}{ Total 2539 } \\
\hline Valid & 127 & 127 \\
\hline Lost & 3 & 3 \\
\hline Mean & 59.5433 & 62.2283 \\
\hline Median & 61.0000 & 64.0000 \\
\hline Mode & 66.00 & 66.00 \\
\hline SD & 5.21712 & 4.67039 \\
\hline Variance & 27.218 & 21.813 \\
\hline Range & 26.00 & 23.00 \\
\hline Minimum & 40.00 & 43.00 \\
\hline Maximum & 66.00 & 66.00 \\
\hline
\end{tabular}

Source. SPSS (2020)

When reviewing the previous data, it can be determined that the most widely accepted model corresponds to Decree 2539 because the values are more consistent and responses are less disperse.

\section{Conclusions}

Once the statistical variables have been reviewed, no correlation is found between the models of the private and the public sector, that is, the relationship between the models analyzed is not statistically significant. Therefore, the Spencer \& Spencer model is not valid for the public sector.

The model of Decree 2539 has greater acceptance in the public sector, as it belongs to the functional current instead of the behavioral one, e.g. Spencer \& Spencer, which is undeveloped in that sector. The competencies model of Decree 2539 has to be entered with the organizational development competency that refers to better performing their work in the institution.

The element with least competition is teamwork. People are not interested in developing their skills in the public sector because the hiring system does not stimulate self-development. Among those surveyed, administrative roles had no relation to educational level, thus they are disincentivizing the development of management skills.

On the other hand, one of the limitations refers to the sample that was surveyed. In some public institutions the issue of competencies did not seem important due to their development or for fear of the existing difference. Another limitation refers to the application of the instrument to a single sector, that is, the public model could be validated in the private sector.

Lastly, limiting the assessment to the eleven management competencies in Spencer \& Spencer's model does not exhaust the possible universe of skills in the professional management field.

\section{References}

[1]. Burke, W. W. (2017). Organization change: Theory and practice. Sage publications.

[2]. O'Donnell, D., \& Garavan, T. N. (1997). Linking training policy and practice to organizational goals. Journal of European Industrial Training, 21(9), 301-309.

[3]. Alles, M. A. (2006). Dirección estratégica de recursos humanos. Ediciones Granica SA.

[4]. Fierro Martínez, Á. M. (2007). Diagnostico empresarial: un enfoque para el análisis financiero integral (No. 658 F463d Ej. 1). Ediciones Unicesar.

[5]. Spencer, L. M., \& Spencer, P. S. M. (2008). Competence at Work models for superior performance. John Wiley \& Sons.

[6]. Gumbau Albert, M. (1998). La eficiencia técnica de la industria española. Revista española de economía, 15(1), 067-84.

[7]. Hamel, G., \& Prahalad, C. K. (1994). Competing for the future. Harvard business review, 72(4), 122-128.

[8]. Echebarría, K., \& Mendoza, X. (1999). La especificidad de la gestión pública: el concepto de management público. De burócratas a gerentes, 1546.

[9]. Ortiz, H. (2011). Análisis financiero aplicado y principios de administración financiera (Vol. 12). Colombia: Universidad Externado de Colombia.

[10]. Henderson, R., \& Cockburn, I. (1994). Measuring competence? Exploring firm effects in pharmaceutical research. Strategic management journal, 15(S1), 6384.

[11]. McClelland, D. C. (1973). Testing for Competence Rather than for. American Psychologist, 28(1), 1-14.

[12]. Elizondo, M. M., Armenteros Acosta, M. D. C., Guerrero Ramos, L., \& Barquero Cabrero, J. D. (2012). Las Competencias Gerenciales Desde Una Visión Estratégica de las Organizaciones: Un Procedimiento Para Su Identificación y Evaluación del Desempeño (Managerial Skills from a Strategic Viewpoint: A Procedure for Their Identification and Performance Assessment). Revista internacional administración \& finanzas, 5(2), 79-100.

[13]. Mertens, L. (1997). Competencia laboral: sistemas, surgimiento y modelos. Cinterfor. Montevideo.

[14]. Saracho, J. M. (2005). Un modelo general de gestión por competencias. Modelos y metodologías para la identificación y construcción de competencias. RIL editores.

[15]. Hall, E., \& Hall, M. (1990). Understanding cultural differences: "Germans, French and Americans" (Vol. 9). EEUU: Intercultural Press Inc.

[16]. Rodríguez, A. S., Fornaris, C. E. M., \& Martínez, C. C. M. (2005). Una mirada a los orígenes de las Competencias Laborales. Ciencias Holguín, 11(2), 114.

[17]. Brockmann, M., Clarke, L., \& Winch, C. (2009). Competence and competency in the EQF and in European VET systems. Journal of European Industrial Training, 33(8/9), 787-799.

[18]. Hoffmann, T. (1999). The Meanings of Competency. Journal of European Industrial Training, 23(6), 275-85. 
[19]. Lucia, A. D., \& Lepsinger, R. (1999). Art \& science of competency models. San Francisco, CA: JosseyBass.

[20]. Boyatzis, R. E. (1982). The competent manager: A model for effective performance. John Wiley \& Sons.

[21]. Dubois, D. D. (1993). Competency-based performance improvement: A strategy for organizational change. HRD Press, Inc., 22 Amherst Road, Amherst, MA 01002.

[22]. Zúñiga, F. V. (2004). 40 preguntas sobre competencia laboral (Vol. 13). Cinterfor.

[23]. Rodriguez, D., Patel, R., Bright, A., Gregory, D., \& Gowing, M. K. (2002). Developing competency models to promote integrated human resource practices. Human Resource Management: Published in Cooperation with the School of Business Administration, The University of Michigan and in alliance with the Society of Human Resources Management, 41(3), 309-324.

[24]. Sanghi, S. (2016). The handbook of competency mapping: understanding, designing and implementing competency models in organizations. SAGE publications India.

[25]. Fogg, C. D. (1999). Implementing your strategic plan: How to turn" intent" into effective action for sustainable change. Amacom Books.

[26]. Damm, L., \& Szmulewicz, P. (2007). Modelo genérico de gerente de Spencer y Spencer. Una aplicación a la Hotelería. Gestión Turística, (7),55-80.

[27]. Gilbert, P. (2006). La compétence: concept nomade, significations fixes. Psychologie du Travail et des Organisations, 12(2), 67-77.

[28]. Ruiz, M. J. C. (2012). Las competencias laborales como predictoras del desempeño en una empresa del sector del juego (Doctoral dissertation, Universidad de Murcia).
[29]. Sánchez, J. (2014). Las competencias profesionales en el ejercicio de la abogacía (Doctoral dissertation, Tesis de doctorado). Universidad Ramon Llull, Barcelona, España).

[30]. Burke, J. M., Miller, W. A., Spencer, A. P., Crank, C. W., Adkins, L., Bertch, K. E., ... \& Valley, A. W. (2008). Clinical pharmacist competencies: American college of clinical pharmacy. Pharmacotherapy: The Journal of Human Pharmacology and Drug Therapy, 28(6), 806-815.

[31]. del Pino Medina, J. M., Gómez Milán, E., \& Moreno Rios, S. (2015). Multiple intelligence and performance in football. Apunts. Educació Fisica $i$ Esports, (121), 44-55.

[32]. Boyatzis, R. E. (2008). Competencies in the 21st century. Journal of Management Development, 27(1), $5-12$.

[33]. Boyatzis, R. E., Goleman, D., \& Rhee, K. (2000). Clustering competence in emotional intelligence: Insights from the Emotional Competence Inventory (ECI). Handbook of emotional intelligence, 99(6), 343-362.

[34]. Goleman, D. (2018). Inteligencia emocional en la empresa (Imprescindibles). Conecta.

[35]. Cuevas Romo, A., Méndez Valencia, S., \& Hernández-Sampieri, R. (2014). Manual de introducción a ATLAS. ti 7. Universidad de Celaya, Instituto Politécnico Nacional.

[36]. Bonilla, C., \& Rodríguez, S. (2005). La Investigación en Ciencias Sociales. Editorial Norma.

[37]. Cerda Gutiérrez, H. (2011). Los elementos de la investigación: cómo reconocerlos, diseñarlos y construirlos (No. Q180. 55. M4 C46).

[38]. González Alonso, J., \& Pazmiño Santacruz, M. (2015). Cálculo e interpretación del Alfa de Cronbach para el caso de validación de la consistencia interna de un cuestionario, con dos posibles escalas tipo Likert. Revista publicando, 2(1), 62-67. 